ORIGINAL ARTICLE

\title{
Frequency of Helicobacter Pylori Infection in the Local Population Presenting with Dyspeptic Symptom
}

\author{
MUHAMMAD ZARRAR ${ }^{1}$, SHAHZAD MEMON², KASHIF ALI ${ }^{3}$, ARSALAN BADAR ${ }^{4}$, YAR MUHAMMAD ${ }^{5}$, ROZINA MUJEEB $^{2}$ \\ SAHITO ${ }^{6}$ \\ ${ }_{1,2,4}$ Assistant Professor Medicine, PUMHSW, Nawabshah \\ ${ }^{3}$ Assistant Professor Medicine, Bilawal Medical College for boys Jamshoro \\ ${ }^{5}$ Assistant Professor Medicine, GIMS Gambat \\ ${ }^{6}$ Assistant Professor, Gynae and OBS PUMHSW, NawabshahCorrespondence to: Dr. Kashif Ali, Email: fazlanikashif@gmail.com
}

\begin{abstract}
Objectives: To determine the frequency of Helicobacter pylori infection in the local population presenting with dyspeptic symptom report to a tertiary care hospital of Nawabshah.

Methodology: This cross-sectional study took place at department of medicine, Peoples Medical College and Hospital Nawabshah; during six months, form August 2015 to February 2016. A total of 115 patients with dyspeptic symptoms with upper abdominal disorders such as discomfort and pain, nausea, fullness, bloating, heartburn, anorexia, belching and regurgitation were included. After conducting detailed clinical examination and history, patients were subjected to relevant examinations, i.e. Blood antibody test (IgA antibody test), for $\mathrm{H}$. pylori and venous blood was drawn. All the information was collected in the proforma.

Results: The patients' average age was $30.92 \pm 6.10$ years. There were $66(57.4 \%)$ male cases and $49(42.6 \%)$ female cases. Helicobacter pylori $(H$. pylori) infection was observed to be frequent $(60 \%$ cases) among both genders.

Conclusion: In conclusion, the present results confirm that the frequency of patients suffering from helicobacter pylori infection was quite high in local population at tertiary care hospital, Nawabshah. Strategies could be developed at an earlier stage and prompt treatment may reduce the morbidity.

Key Words: Dyspepsia, Helicobacter pylori, IgA antibody test
\end{abstract}

\section{INTRODUCTION}

Dyspepsia is a digestive disorder characterized by difficult, painful, or disrupted digestion, and can possibly also appear with the symptoms of nausea and heartburn, vomiting, stomach discomfort, and bloating. ${ }^{1}$ Dyspepsia is a common symptom experienced by around $25-40 \%$ of general population annually, however a large number of affected individuals do not consult a doctor. ${ }^{2}$ Dyspepsia is accountable for a significant amount of health-care expenditures and wasting of working time. ${ }^{3}$ The incidence of this medical condition has been reported to be strongly linked to socioeconomic status and growing age. ${ }^{4}$ In adult population of the West, the incidence of dyspepsia ranges between $10 \%$ and $20 \%,{ }^{5}$ and in Pakistan it is unknown, but it is thought to be prevalent, as $20-25 \%$ of patients with dyspepsia seek medical advice. ${ }^{5}$ Helicobacter pylori $(\mathrm{H}$. pylori) is a widespread infection that affects over $50 \%$ of the adultsglobally. ${ }^{6,7} \mathrm{H}$. pylori is linked to serious conditions of Gl-tract (upper gastrointestinal tract) in both children and adults. $H$. pylori has affected over half of the global population, with highest incidence recorded in underdeveloped nations like $30 \%$ in USA and Canada, $82 \%$ in Bangladesh, $88 \%$ in India, $20 \%$ in Australia and $80 \%$ in Saudi Arabia. Although some studies have found that $\mathrm{H}$. pylori-infected people are more likely to experience dyspepsia, ${ }^{8}$ the link betweendyspepsia and $\mathrm{H}$. pylori is still debated. Studies reported that $\mathrm{H}$. pylori infected patients presented with dyspepsia symptoms like abdominal pain, epigastric pain, anorexia, weight loss, nausea, vomit, heart burn, bloating, belching, melena, dysphagia and gastric fullness. ${ }^{9,10}$ The American College of Gastroenterology (ACG) guidelines 2005 for dyspepsia management recommended $H$. pylori infection assessment among patients with dyspepsia without "Alarming features" as the most cost-effective and preferred approach. ${ }^{11}$ This study aimed at assessing the frequency of $\mathrm{H}$. pylori infection within local population with dyspeptic symptom reporting at a tertiary care hospital of Nawabshah.

\section{MATERIAL AND METHODS}

This cross-sectional study was conducted at Medical department of Peoples Medical College \& hospital Nawabshah. Study duration was six months from August 2015 to February 2016. All the patients regardless of sex and $\geq 18$ years were admitted to the medicine department through OPD (outpatient department) with any of the two outcomes of the dyspeptic symptoms such as upper abdominal disorders like discomfort and pain, nausea, fullness, bloating, heartburn, anorexia, belching and regurgitation were included. Patients with peptic ulcer disease (PUD), those who had undergone eradication therapy for $\mathrm{H}$. pylori, those who had been on prolonged NSAID therapy, as well as those who were positive for Anti-HCV/HBsAg were all excluded. All thepatients gave an informed written consent before participating in the study. Subjects fulfilling the inclusion criteria were interviewed using the pre-tested questionnaire. The interview was conducted by the principal researcher at outpatient department of Peoples Hospital Nawabshah. After detailed clinical examination and receiving history, patients were subjected to relevant examinations i.e. Blood antibody test ( $\lg \mathrm{A}$ antibody test) for $\mathrm{H}$. pylori and venous blood was drawn. Proforma (Attached Annexure A) was filled accordingly. All the information regarding study variables (age, sex, socioeconomic status, abdominal discomfort and pain, nausea, bloating, anorexia, fullness, heartburn, belching and regurgitation) linked to H.Pylori was 
collected via self-made study proforma. SPSS version 20 was used for the purpose of analysis.

\section{RESULTS}

A total of 115 diagnosed cases of peptic ulcer disease were studied and the mean age of these cases was $30.92 \pm 6.10$ years. The average duration of disease was $3.51 \pm 1.74$ months. Out of 115 patients, males and females were $66(57.4 \%)$ and $49(42.6 \%)$ respectively. Regarding socio economic status, most of the cases were from lower and middle class. Abdominal pain and discomfort was the commonest symptoms that was observed in $87.8 \%$ cases followed by $71.3 \%$ cases nausea $48.7 \%$, fullness $47.8 \%$ other symptoms is also presented in table 1.

Table. 1. Descriptive statistics of demographic characteristics of the patients $\mathrm{n}=115$

\begin{tabular}{|l|l|l|}
\hline Variables & Statistics \\
\hline Age (mean+SD) & & $30.92+6.10$ \\
Duration of disease & $($ mean+SD) & $3.51+1.74$ \\
\hline \multirow{3}{*}{ Gender } & Males & $66(54.4 \%)$ \\
\hline \multirow{3}{*}{$\begin{array}{l}\text { Socioeconomic } \\
\text { status }\end{array}$} & Females & $49(42.6 \%)$ \\
\hline \multirow{3}{*}{$\begin{array}{l}\text { Dyspeptic } \\
\text { symptoms }\end{array}$} & Lower class & $54(47.0 \%)$ \\
\cline { 2 - 3 } & Uiddle class & $55(47.8 \%)$ \\
\cline { 2 - 3 } & Upper class & $6(5.2 \%)$ \\
\hline & discominal pain and & $101(87.8 \%)$ \\
\cline { 2 - 3 } & Bloating & \\
\cline { 2 - 3 } & Fullness & $82(71.3 \%)$ \\
\cline { 2 - 3 } & Nausea & $55(47.8 \%)$ \\
\cline { 2 - 3 } & Anorexia & $56(48.7 \%)$ \\
\cline { 2 - 3 } & Heartburn & $40(34.8 \%)$ \\
\cline { 2 - 3 } & Regurgitation & $53(46.1 \%)$ \\
\cline { 2 - 3 } & Belching & $53(39.1 \%)$ \\
\hline
\end{tabular}

FREQUENCY OF H. PYLORI

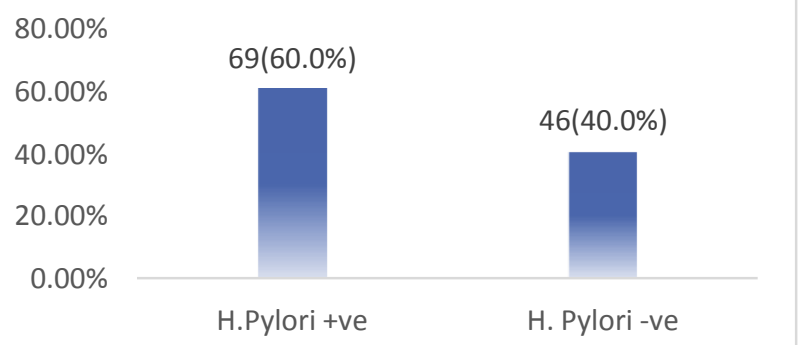

Figure 1: Frequency of Helicobacter Pylori Infection $n=115$

Table 2: Frequency of helicobacter pylori infection with respect to age groups $n=115$

\begin{tabular}{|c|c|c|c|c|c|}
\hline \multirow{2}{*}{\multicolumn{2}{|c|}{ Variables }} & \multirow[t]{2}{*}{ Total } & \multicolumn{2}{|c|}{$\begin{array}{l}\text { Helicobacter } \\
\text { pylori infection }\end{array}$} & \multirow{2}{*}{$\begin{array}{l}\mathrm{p} \text { - } \\
\text { value }\end{array}$} \\
\hline & & & Yes & No & \\
\hline \multirow{5}{*}{ Age groups } & $18-20$ & 6 & 3 & 3 & \multirow{5}{*}{0.87} \\
\hline & $21-25$ & 21 & 12 & 9 & \\
\hline & $26-30$ & 29 & 16 & 13 & \\
\hline & $31-35$ & 26 & 17 & 9 & \\
\hline & $36-40$ & 33 & 21 & 12 & \\
\hline \multirow[b]{2}{*}{ Gender } & Male & 66 & 43 & 23 & \multirow[b]{2}{*}{0.19} \\
\hline & Female & 49 & 26 & 23 & \\
\hline \multirow{3}{*}{$\begin{array}{l}\text { Socioeconomic } \\
\text { status }\end{array}$} & UpperClass & 6 & 5 & 1 & \multirow{3}{*}{0.39} \\
\hline & MiddleClass & 55 & 34 & 21 & \\
\hline & LowerClass & 54 & 30 & 24 & \\
\hline
\end{tabular}

Frequency of helicobacter pylori infection was observed in $60 \%(69 / 115)$ cases as presented in figure 1.

Rate of helicobacter pylori infection was statistically insignificant according to the age, gender and socioeconomic status $(p=>0.05)$. Table.2

\section{DISCUSSION}

Dyspepsia is a costly and long-term illness. In most cases, the symptoms of brief or of minor severity are reported, and they can be self-managed. Testing against $\mathrm{H}$. pylori infection and managing all infected individuals empirically using antimicrobial medication has been the most effective therapeutic method for patients of age 55 years or below presenting with fresh-onset of dyspepsia without alarming features. In this study, the patients' mean age was 30.926.10 years. Furthermore, the difference in the $\mathrm{H}$. pylori infection rate between age groups was statistically insignificant $(p=0.08)$. According to available evidence, the acquisition of $\mathrm{H}$. pylori occurs in early age via interpersonal contact within the environment (particularly in underdeveloped nations) and contact between family members, possibly via faecal-oral or oro-oral routes, and if left untreated, the bacterium can persist permanently. ${ }^{12}$

In present study abdominal pain and discomfort was the commonest symptom that was observed in $87.8 \%$ cases followed by $71.3 \%$ cases nausea $48.7 \%$, fullness $47.8 \%$ other symptoms. It was also reported by Malik et al ${ }^{13}$ that the most $(90 \%)$ patients complained of upper abdominalpain and retrosternal burning. Other symptoms were regurgitation $(65 \%)$, nausea $(55 \%)$ and vomiting $(30 \%)$; some patients also had haematemesis (4.5\%). In $\operatorname{Iran}^{10}$ the

$H$. pylori prevalence in heartburn cases was $89.7 \%$, and this prevalence was similar to the prevalence of abdominal pain. Generally, heartburn and gasteoesophageal reflux disorder (GURD) were frequent among $H$. pylori-negative cases. ${ }^{14}$

A higher percentage of our patients $(60 \%)$ in our study had $\mathrm{H}$. pylori infection. Previous research suggested an incidence rate of $80-90 \%$ in underdeveloped nation and local data by Afzal $S$ et al and Fareed et al suggested an incidence of $60-85 \% .{ }^{19,20} \mathrm{~A}$ few Pakistani studies including Butt AK et al., reported the prevalence ranging between $40 \%$ and $57 \% .{ }^{21}$ Faisal et al found $39.8 \%$ incidence of $\mathrm{H}$. pylori, ${ }^{22}$ and Mohsin $\mathrm{L}$ et al found $43.6 \%$ incidence. ${ }^{23}$ However, a local study done by Baqai $R$ et al 24 suggested $60.5 \%$ incidence, which is analogous to ours.

In India, 38 asymptomatic and 49 symptomatic individuals (56.7\% and $61.3 \%$ respectively) were infected with $\mathrm{H}$ pylori. ${ }^{25}$ In Saudi-Arabia, out of 488 dyspeptic cases, $54.90 \%$ of gastric biopsies were positive for $H$ pylori. ${ }^{26}$ In Yemen, out of 275 dyspeptic cases, $82.2 \%$ were positive for H pylori. ${ }^{27}$ In Jordan, out of 197 patients, $82 \%$ cases were positive for $\mathrm{H}$ pylori. ${ }^{28}$

In this study out of 115 patients, male and female patients were 66(57.4\%) and 49(42.6\%) respectively. Most of the cases were from lower and middle class. However, association between gender and $H$. pylori positivity was statistically insignificant $(p=0.19)$. Males were shown to be at a higher risk of infection in some research studies, whereas infection rates were found to be independent of sex in other studies. ${ }^{25}$ In our study, no association was found between $H$. pylori infection and socioeconomic status. 
In a study from Kuwait ${ }^{10}$ on dyspeptic patients, $\mathrm{H}$. pylori infection among young females (38\%) was significantly more common as compared to males(10.5\%), ( $p=0.008)$; however, overall no difference was found in terms of sex (females $43.2 \%$ Vs males $42.2 \%$ ). This suggests that Kuwaiti female patients are infected with $\mathrm{H}$. pylori at anearlier age as compared to male patients, which could lead to a more severe disease with a longer infection period. In a Norwegian population-based study, ${ }^{26}$ the $H$. pylori infection distribution in terms of dyspepsia was uneven in both genders. Furthermore, infection with $\mathrm{H}$. pylori has decreasedirrespective of dyspepsia, particularly in younger people. In $\mathrm{H}$. pylori infected patients, screening and treatment is expected to be more effective than other techniques, and the effect of this approach is probably minimal in case of non- prevalent infection. Furthermore, studies on cost- effectiveness indicate that noninvasive screening should be chosen as per the community's infection prevalence. The urea breath tests or stool antigen tests are the most frequently performed tests in intermediate and low prevalence circumstances. The accuracy of these screening modalities increases with increasing costs. As a result, evaluating the frequency of $\mathrm{H}$. pylori in the populationis essential for selecting the best costeffective management plan for patients with unidentified dyspepsia.

\section{CONCLUSION}

In conclusion, the present results confirm that the frequency of patient suffer from helicobacter pylori infection was quite high in local population at tertiary care hospital Nawabshah. Strategies could be developed at an earlier stage and prompt treatment may be initiated to reduce the morbidity. Physicians who diagnose and treat patients with dyspepsia should seriously consider $H$. pylori as an importantetiological agent.

\section{REFRENCES}

1. Musana AK, Yale SH, Lang KA. Managing Dyspepsia in a Primary Care Setting. Clin Med and Rese. 2006;4:337-42.

2. Malik MF, Hussain T, Khan MN, Mirza SA, Faroo M. Helicobacter pylori infection in patients with dyspeptic symptoms having normal endoscopy. Pak Armed Forces Med J. 2010;4:23-25.

3. Khan N, Shabbir G, Zarif M, Khattak MI. Upper gastrointestinal endoscopic assessment of patients presenting with dyspepsia. J Post Med Inst. 2007;21:212-6.

4. Levy R, Olden K, Naliboff B. Psychosocial Aspects of the Functional Gastrointestinal Disorders. Gastroenterol. 2006;130:1447-8.

5. Danesh J, Lawrence M, Murphy M, Roberts S, Collins R. Systematic review of the epidemiological evidence on helicobacter pylori infection and nonulcer or uninvestigated dyspepsia. Arch Intern Med. 2000;160:1192-8

6. Tijjani B, Umr A. Peptic ulcer disease and helicobacter pylori infection at Kano, Nigeria. Int J Gastroenterol. 2009;8:16-19.

7. Chong $\mathrm{V} \mathrm{H}$, Lim K C, Rajendran N. Prevalence of active helicobacter pylori infection among patients referred for endoscopy in Brunei Darussalam. Singapore Med J. 2008;49:42-6.
8. Tadege T, Mengistu Y, Desta K, Asrat D. Seroprevalence of helicobacter pylori infection in and its relationship with $\mathrm{ABO}$ blood groups. Ethiop J Health Dev. 2005;19:55-9.

9. Alazmi WM, Siddique I, Alateeqi N, Al-Nakib B. Prevalence of helicobacter pylori infection among new outpatients with dyspepsia in Kuwait. BMC Gastroenterol. 2010;10-14.

10. Shokrzadeh L, Baghaei K, Yamaoka Y, Shiota S, Mirsattari D, Porhoseingholi, Zali MR. Prevalence of Helicobacter pylori infection in dyspeptic patients in Iran. Gastroenterology Insights 2012; 4:24-8.

11. Talley N, Vakil N. Guidelines for the management of dyspepsia. Am J Gastroenterol. 2005;100:2324-37

12. Sherman PM. Appropriate strategies for testing and treating Helicobacter pylori in children: when and how? Am J Med. 2004;117:30S-5S.

13. Malik KA, Shaikh R, Rehman S. Prevalance of helicobacter pylori indyspeptic patients at lyari general hospital. Oak J Surg. 2004;23:33-35.

14. Shiota S, Murakami K, Takayama A, et al. Evaluation of Helicobacter pylori status and endoscopic findings among new outpatients with dyspepsia in Japan. J Gastroenterol. 2009;44:930-4.

15. Fareed R, Abbas Z, Shah MA. Effect of Helicobacter pylori density on inflammatory activity in stomach. J Pak Med Assoc. 2000;50:148-51.

16. Afzal S, Ahmad M, Mubarik A, Saeed F, Rafi S, Saleem N, et al. Morphological spectrum of gastric lesion- endoscopic biopsy findings. Pak armed forces med J. 2006;2.

17. Butt A K, Khan A A, Khan A A, Izhar M, Alam A, Shah S W H et al. Correlation of Helicobacter Pylori in Dental Plaque and Gastric Mucosa of Dyspeptic Patients. J Pak Med Assoc. 2002;52:196-200.

18. Faisal N, Ashraf P, UIHaq, MN, Helicobacter pylori infection; dyspeptic patients undergoing endoscopy: a hospital based study. Professional Med J. 2012;19:202-7

19. Mohsin A, Qayyum A, Hussain I, Mirza A, Shah AA, Zaidi SNR. Helicobacter Pylori Prevalence and Eradication(HAPPEN) Study: Helicobacter Pylori Prevalence: An experience with patients presenting to Jinnah Hospital, Lahore. Ann King Edward Med Coll. 1999;5:95-6.

20. Baqai R, Qureshi H, Arian G, Mehdi I. Diagnostic efficacy of stool antigen test (hpsa), clo test and serology for the detection of helicobacter pylori infection, http://www.ayubmed.edu.pk/JAMC/PAST/15- 4/Rbaqai.htm.

21. Singh V, Trikha B, Nain CK, Singh K, Vaiphei K. Epidemiology of Helicobacter pylori and peptic ulcer in India. J Gastroenterol Hepatol.2002;17: 659-65.

22. Ayoola AE, Ageely HM, Gadour MO, Pathak VP. Prevalence of Helicobacter pylori infection in patients with dyspepsia in South-Western Saudi Arabia. Saudi Med J.2004;25:1433-38

23. Gunaid AA, Hassan NA, Murray-Lyon I. Prevalence and risk factors for Helicobacter pylori infection among Yemeni dyspeptic patients. Saudi Med J.2003;24:512-17

24. Bani-Hani KE, Hammouri SM. Prevalence of Helicobacter pylori in Northern Jordan. Endoscopy based study. Saudi MedJ.2001;22:843-47

25. Replogle ML, Glaser SL, Hiatt RA, Parsonnet J. Biologic sex as a risk factor for Helicobacter pylori infection in healthy young adults. Am J Epidemiol. 1995;142:856-63.

26. Asfeldt AM, Straume B, Steigen SE, Løchen ML, Florholmen $\mathrm{J}$, Bernersen B, et al. Changes in the prevalence of dyspepsia and Helicobacter pylori infection after 17 years: the Sørreisa gastrointestinal disorder study. Eur J Epidemiol. 2008;23:62533. 